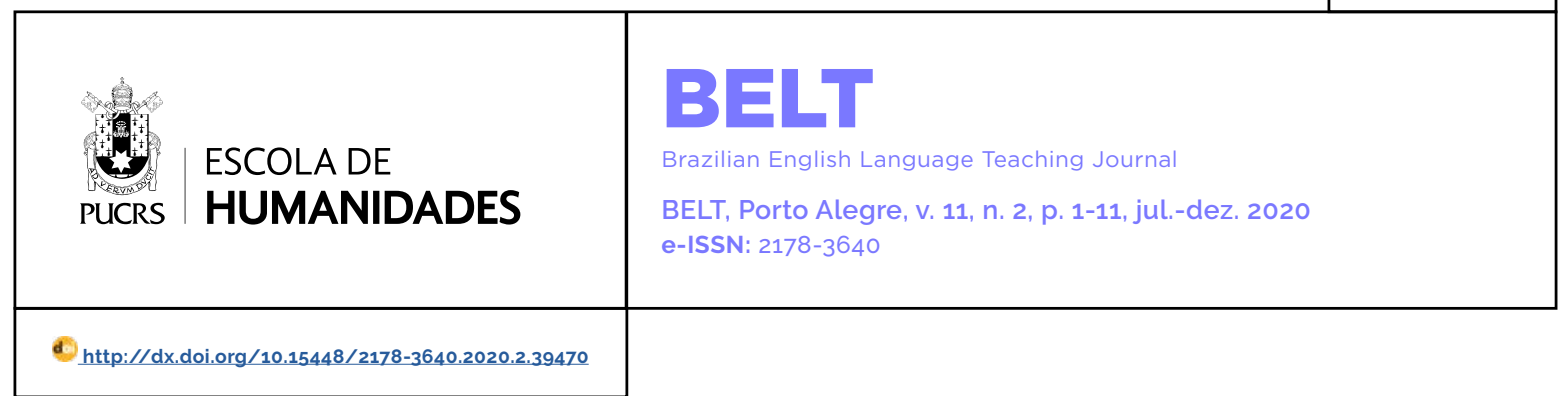

\title{
Lessons Learned Piloting an EMI Support Course at a Southern Brazilian University
}

\author{
Lições aprendidas na primeira edição de um curso de apoio de EMI em uma \\ universidade do sul do Brasil
}

\author{
Kerry Pusey ${ }^{1}$ \\ orcid.org/0000-0001-7178-0620 \\ kpusey@upenn.edu
}

Received on: 03/11/2020. Approved on: 21/01/2021 Published on: 29/03/2021

\section{(c) (i)}

Artigo está licenciado sob forma de uma licença Creative Commons Atribuição 4.0 Internacional.
Abstract: While the literature on English as a medium of instruction (EMI) has seen steady growth over the last two decades, the topic of pre- and in-service teacher education for EMI has received relatively little attention-a situation that is even more marked within the context of Brazilian higher education. Responding to this gap with a practice-oriented contribution, this paper distills some of the major insights gained from piloting an EMI support course at a private university in the south of Brazil. The paper is organized around five themes, or 'lessons learned, which represent the most salient takeaways from the piloting experience. These lessons intersect with some of the most pressing issues faced by researchers, practitioners, and policymakers involved with EMI in higher education contexts. By aligning theoretical and practical concerns, the paper seeks to establish an agenda for further investigation into EMI teacher education-especially within the Brazilian context.

Keywords: English as a medium of instruction, teacher education, curriculum development, Brazilian higher education, internationalization.

Resumo: As atividades de pesquisa em Inglês como Meio de Instrução (English as a Medium of Instruction-EMI) têm crescido nas últimas duas décadas; não obstante, a formação inicial e contínua de professores de EMI tem recebido pouca atenção até agora-uma situação que é ainda mais evidente no contexto da educação superior no Brasil. Respondendo a essa lacuna, com uma contribuição orientada à prática, este artigo apresenta algumas das lições mais importantes que emergiram ao pilotar um curso de treinamento para EMI em uma universidade privada no sul do Brasil. O artigo está organizado em cinco temas, ou 'lições aprendidas,' que correspondem a novas áreas de conhecimento, resultadas da experiência piloto. Essas lições se interrelacionam com algumas das questões mais urgentes encaradas por pesquisadores, professores, e elaboradores de políticas vinculadas a EMI no contexto da educação superior. Ao alinhar áreas práticas e teóricas, este artigo busca chamar atenção para a necessidade de mais investigações sobre a formação de professores em EMI-sobretudo no contexto do Brasil.

Palavras-chave: Inglês como Meio de Instrução, formação de professores, desenvolvimento do currículo, educação superior no Brasil, internacionalização.

\section{Lessons Learned Piloting an EMI Support Course at a Southern Brazilian University}

In Brazil, as in other parts of the world, a steadily growing number of universities are beginning to offer courses taught through the medium of English. According to a 2018 survey commissioned by the British Council, 72 universities in Brazil were currently offering or were planning to offer EMI courses (Gimenez et al., 2018, pp. 14-17). However, the actual number of universities offering EMI classes is likely much higher, considering 
that the number of respondent institutions ( $n=$ 84) was less than one third of the total number of universities contacted ( $n=270$ ), which was in turn much lower than the approximately 2,500 higher education institutions (HEIs) that exist in the country (Times Higher Education, n.d.). A case in point is Southern Brazilian University (SBU, a pseudonym used throughout the paper), a private university in the south of Brazil, which, in 2019, had approximately $20 \mathrm{EMI}$ courses on offer across undergraduate and graduate levels, with a total of 246 students enrolled, yet was not included in the 2018 British Council survey.

In response to the growing demand for EMI, and the common lament that pre- and in-service EMI instructors lack appropriate training for teaching courses through the medium of English (cf. Ball \& Lindsay, 2013; Martinez, 2016), an EMI support course was created at SBU. The EMI support course was designed to help prepare interested faculty at SBU for the linguistic and pedagogical challenges associated with EMI. It was also intended to raise faculty awareness of the many issues (i.e., educational, sociological, cultural, political) involved in EMI implementation. The impetus for creating the EMI support course came from the availability of a dedicated visiting faculty member (the author of the present paper) to work with local Brazilian faculty (applied linguists at the University) to carry out a curriculum development project. After several initial meetings between the visiting professor and local faculty, it was determined that an EMI support course would be a welcomed and innovative initiative at the University.

With that, the visiting professor and local faculty set about designing the course, using the curriculum development model proposed by Nation and Macalister (2010). The curriculum development process is discussed in detail elsewhere (Pusey et al., 2021), but briefly, the course included a total of 48 contact hours, with meetings held bi-weekly over two semesters. The course initially had a total of 25 participants, but due to various scheduling conflicts (a key constraint in the environment analysis; see Pusey et al., 2021), only 10 faculty members completed the entire course. The principal aims of the course were to develop teachers' knowledge of language, communication, and pedagogy for EMI, as well as to raise their awareness of historical and contemporary issues (i.e., challenges, policies, relative advantages and disadvantages) connected to EMI implementation. The course culminated with a curriculum development project, which required the faculty participants to create and formally present an EMI course proposal to the class, with the hope that these proposals could actually be used in the future. (Most of the faculty members were not currently teaching EMI courses.) The EMI support course was registered as a curso de extensão (continuing studies course) at the University, and participants who finished the course received a certificate of completion.

The development, implementation, and evaluation of the EMI support spanned over the entire academic year of 2019. Throughout this time, and in the weeks and months after the course had finished, the course developers had many opportunities to reflect on the course, discuss impressions, observations, and conversations they had had with participating faculty members, as well as analyze course evaluation data and course outcomes. Through these activities, and as a result of the piloting experience more generally (i.e., reviewing literature, planning lessons, getting to know the faculty participants, trying out new activities), a number of insights emerged. These insights and their implications for EMI teacher training are described below.

\section{Five Lessons Learned}

In what follows, I attempt to encapsulate insights gained from piloting an EMI teacher support course within five broad categories, which I have termed 'lessons learned.' For each 'lesson,' I give a brief overview, and then discuss how the topical area might be integrated into the curriculum of future EMI teacher education programs.

\section{Grassroots Teacher Education}

As alluded to above, there is a shortage of EMI teacher education opportunities that exist 
in Brazil, and a limited body of research on the outcomes of the programs that do exist (see Martinez, 2016). This, unfortunately, is characteristic of the situation globally (Macaro et al., 2018), and is one of the enduring challenges to EMI implementation. However, even in cases where some form of EMI support does exist, the assumption that participating in a shortterm professional development opportunity will lead to sustained changes in EMI practice is somewhat doubtful (Drljača Margić \& VodopijaKrstanović, 2018). What is more likely to enhance the pedagogical, linguistic, and communicative practices of EMI instructors in the long term is a personal commitment to lifelong learning, and the grassroots mobilization of like-minded individuals towards the accomplishment of shared professional development goals.

A grassroots approach to professional development is an empowering move that sidesteps institutional dependency and places the onus of learning and self-improvement on the agents who seek change (e.g., Farrell, 2019). Three 'bottom-up' approaches are particularly promising in this regard: reflective teaching, action research, and the establishment of communities of practice.

\section{Reflective teaching}

Reflective practice requires that teachers "subject their [educational] philosophy, principles, theories and practices to a critical analysis so that they can take more responsibility for their actions" (Farrell, 2019, p. 2). Of particular relevance in the preceding quote is the idea of 'taking responsibility for one's actions.' By engaging in reflective practiceespecially in the absence of ostensive institutional support, EMI instructors assume an active, agentive subject position; they take the initiative to learn about what they do in the classroom and how they might do it differently in order to improve the learning experiences of their students, as well as their own experience as teachers.

\section{Action research}

Action research is often considered a form of reflective teaching (Burns, 2010; Farrell, 2019; Richards \& Lockart, 1996), but is decidedly more involved, typically involving the steps of observation, reflection, planning, action, and evaluation. As a result, action research might produce more effective outcomes than reflective practice alone (Farrell, 2019). As a form of grassroots teacher education, action research allows practitioners to discover specific problems or challenges in their classrooms, to investigate those problems systematically, and to make changes in their professional practice based upon the results of their investigations. The results are thus directly relevant to their contexts of teaching, though often have implications for others in similar teaching contexts as well. Reflective practice and action research were two themes that were taken up in the EMI support course, which teachers seemed to highly value as a viable means of ongoing professional development (even though most participants were not teaching EMI classes during the time that the support course was given).

\section{Communities of practice}

A community of practice is "a group of people who share a concern or a passion for something they do and learn how to do it better as they interact regularly" (Wenger-Trayner \& WengerTrayner, 2015, p. 1). When teachers have a forum and a public for exchanging thoughts, practices, and ideas, as well as sharing hardships and challenges (i.e., commiserating), posing questions, and offering solutions, they assume a mutually beneficial position which allows them to acquire new skills and change their participation patterns in the community (Kanno \& Norton, 2003). In the current digital age, the possibilities for engaging in communities of practice are vast, and if not available locally, may be accessible virtually through online professional learning networks. The establishment of a community of practice was an explicit aim of the EMI Support Course, and turned out to be one of the course's most noteworthy achievements. This was noted consistently throughout the course by course participants and in the evaluation data.

Whether accomplished locally or virtually (e.g., through online communities of practice), "a bottom-up approach to professional 
development" (Farrell, 2019, p. 2) may help sustain and extend the learning opportunities introduced initially in EMI teacher education programs. Grassroots approaches, such as reflective teaching, action research, and the establishment of communities of practice, may help ensure that the skills, knowledge, and strategies acquired in professional learning forums (e.g., an EMI support course) are actually applied, and that they continue to grow and evolve. As we shall see next, however, there is not always consensus on which 'skills, knowledge, and strategies' should be introduced in EMI teacher education courses.

\section{Perspectival Relativity}

One of the many factors that complicates the implementation of EMI is the diverse perspectives and priorities held by the various stakeholders involved (e.g., teachers, students, administrators). For those considering developing an EMI teacher training program, it follows that careful consideration be given to the needs, motives, beliefs, and perceptions of the faculty participants involved (at a minimum), as well as other stakeholders, to the extent possible. In essence, this is a reminder of the important role played by needs analysis, environment analysis, and principles of teaching and learning in curriculum design (Nation \& Macalister, 2010). The results of these analyses should directly inform the selection of course content, the design of learning activities, and the assessment procedures used for the course, among other decisions. Furthermore, curriculum designers and course facilitators must be willing to adapt the course as needed, in accordance with evolving needs, changing environmental constraints, and new insights gained from emerging research and theory.

Two concrete examples of this 'perspectival relativity' from the EMI Support Course include (1) the role of explicit language instruction and (2) perceptions regarding the relative importance of linguistic accuracy vs. communicative and pedagogical prowess.

\section{Explicit language instruction}

The course designers initially intended for the EMI Support Course to focus primarily on discussing key issues related to EMI and internationalization, as well as pedagogical practices and techniques for EMI, with only limited direct focus on language (e.g., useful 'signposting' expressions to help students follow a lecture). However, results of a needs analysis survey administered to faculty before the start of the course revealed overwhelmingly teachers' concerns with linguistic aspects of teaching courses in English (e.g., pronunciation, grammar, lexis). It also revealed their desire for opportunities to practice using English in a 'Low-stakes,' supportive environment in order to increase confidence in using spoken English. The course designers responded to this need by offering optional language-focused classes during the interim periods between the topical classes (i.e., on a bi-weekly basis), to which the faculty participants expressed great satisfaction.

\section{Weighing linguistic accuracy against communication and teaching skills}

Another example of differences in perspective concerns beliefs about the relative importance of linguistic accuracy in EMI, compared to other dimensions of teaching practice-namely, general communication skills and pedagogical practices. For the EMI Support Course designers, the latter were of greater importance and, given time constraints, stood to develop more significantly over the duration of the course. However, based on results from the needs analysis survey, as well as concerns expressed throughout the course, it was apparent that the participants viewed linguistic accuracy (or 'English language proficiency' in the abstract, as opposed to a more concrete construct; cf. Freeman et al., 2015) as the most important factor in determining one's readiness to teach EMI courses. This finding was not unlike the results of Ball and Lindsay's (2013) study (see also Hahl et al., 2016), in which EMI faculty at the University of the Basque Country in Spain rated pronunciation as the most consequential to their teaching, whereas 
their students deemed "methodological abilities... of the teachers... as far more important... in the facilitation of their learning" (p. 51).

Though the course did end up offering additional language-focused classes (as mentioned above), the main (required) topics class made a strong case for conceptualizing language as a social practice, in which an English as a lingua franca (Jenkins, 2014) orientation was proposed as a useful heuristic for understanding the contingent nature of communication among interlocutors in EMI contexts (Canagarajah, 2017; Jenkins \& Leung, 2017). Within this perspective, normative orientations to linguistic accuracy based on native speaker models were deemphasized, and a focus was instead put on strategic competence, accommodation, and the local achievement of communicative success (Canagarajah, 2013; Hahl et al., 2016; Jenkins, 2014).

In sum, curriculum design involves considering the diversity of perspectives held by relevant stakeholders (e.g., faculty, students), whose views may at times contradict one another, or compete with the views held by the course designers themselves. However, this essential aspect of curriculum design ensures that the course is useful and responsive to teachers' needs (Nation \& Macalister, 2010). A related aspect of curriculum design concerns the dynamic environments in which teachers operate, which may also have a profound impact on course design. It is to this topic that we turn next.

\section{Contextual Relativity}

With few exceptions (e.g., Baumvol \& Sarmento, 2019; Martinez, 2016), the vast majority of published research on EMI to date has come from educational contexts in Europe and Asia (Macaro et al., 2018, p. 43). Yet, these contexts of teaching and learning (broadly categorized) may vary considerably from the reality of EMI in Brazil. Specifically, substantial variation among regions and specific programs may exist with respect to the degree of linguistic and cultural heterogeneity; the general level of English proficiency among students and faculty; the history, experience, and preparation for EMI at the universities in question (e.g., whether in-service EMI teacher education programs exist for faculty; cf. Ball \& Lindsay, 2013; Farrell, 2019; Hahl et al., 2016); and the degree to which the university is 'internationalized' (e.g., number of partner universities, number of international students and faculty).

For these reasons, it is essential that EMI programs, as well as teacher education for pre-and in-service EMI instructors, take local constraints and affordances into consideration when designing curricula and training programs, as several scholars have noted elsewhere (Drljača Margić \& Vodopija-Krstanović, 2018; Kling, 2019; O'Dowd, 2018). At USB, where the vast majority of EMI teachers and students are Brazilian native speakers of Portuguese, it became apparent that EMI teachers' task might be qualitatively different than what an EMI teacher in, say, the Netherlands would have to cope with (cf. Wilkinson, 2013). For example, because EMI instructors at USB share an L1 with students, they can draw on a number of bilingual strategies and resources to aid in the teaching of their classes (e.g., translation, code-switching, L1 materials and classroom management strategies), which may facilitate their task to some extent (Kling, 2019).

Nevertheless, whether teaching in a highly multilingual or a primarily bilingual context, it can be argued that "...all [EMI] lecturers [need] to understand the basics of language acquisition processes, as well as to have training in intercultural communication" (Borsetto \& Schug, 2016, p. 14). In particular, if EMI is to facilitate the goals of internationalization-namely, the inclusion of global perspectives and the preparation of students to participate in the global economy-a high degree of interculturality and 'symbolic competence' is needed (Kim, 2009; Kramsch, 2011).

While many shared challenges exist among EMI programs and teachers across the globe. each context is unique and must be planned for accordingly. As Coleman et al. (2018) point out, "There is no such thing as a prototypical EMI environment" (p. 703). This is manifest in (a) the degree and types of language support that 
are provided; (b) the selection and use of class materials; (c) the instructional approach; (d) the degree to which intercultural communication comes into play and thus requires specific planning; and (e) the types of feedback and options for assessment that may be available.

To conclude, contexts in which instructors and students share an L1 and have similar educational experiences may enjoy greater transparency in teacher/student roles and responsibilities, as well as permit the use of a greater number of communicative strategies and language practices (Kling, 2019). EMI instructors operating in such contexts should feel obliged to take advantage of these affordances in order to enhance learning and content mastery in their classes. However, to meet the broader goals of internationalization, EMI instructors must also be versed in fundamental aspects of second language learning and teaching (Pecorari \& Malmström, 2018), as well as intercultural communication (Kim, 2009; Kramsch, 2011).

\section{Interdisciplinarity and EMI}

Another 'lesson learned' from piloting the EMI Support Course at USB is that EMI implementation is an extraordinarily interdisciplinary activity. Planning for EMI programs involves stakeholders from multiple academic departments with diverse disciplinary traditions and may draw on in its execution perspectives from experts in fields as far ranging as international relations, political science, history, anthropology, linguistics, and education. Important goals for EMI teacher education, therefore, include raising awareness of the complexity of EMI implementation, providing ample opportunities for the exchange of perspectives on this implementation, and clarifying how EMI teachers' individual classes, pedagogical practices, and curricular choices fit into the broader framework of internationalization.

In the EMI Support Course at USB, these goals informed the selection of content and regularly figured into the format and presentation of the course (i.e., lesson planning; Nation \& Macalister, 2010). For example, prior to the commencement of the course, an informal 'meet and greet' was held, wherein the faculty participants had a chance meet, ask questions about one another's classes and academic background, and pose initial questions to other faculty and the course facilitators about teaching classes in English. Soon after, during the first official class meeting, the focus of the class was on internationalization, where Knight's (2003) widely cited definition of the concept was analyzed in order to demonstrate the multifaceted nature and goals of internationalization, as well as to introduce the role(s) played by EMI in this larger project. In addition, an International Affairs Analyst from the University spoke on different occasions about the specifics of internationalization at USB (e.g., policies, enrollment data, future initiatives), which helped further frame where EMI and teachers' individual courses fit into the grander scheme of things.

In subsequent meetings, the complexity of EMI (i.e., challenges, relative advantages and disadvantages) was discussed with reference to issues raised in recent papers by notable EMI scholars (e.g., Kling, 2019; Macaro et al., 2018; Pecorari \& Malmström, 2018). Two examples include threshold levels of English language proficiency needed for teaching EMI classes and the potential for 'domain loss' as a result of the increasing preference for research published in English (Shohamy, 2013; Toh, 2016). In almost every class meeting, activities were designed to promote the open exchange of thoughts and opinions, with the aim of broadening participants' perspectives and probing more deeply into the interdisciplinary nature of EMI.

As the preceding discussion has hopefully demonstrated, EMI is inherently interdisciplinary, involving the teaching and learning of content that spans the full disciplinary gamut. Successful EMI implementation requires students and teachers to possess a functional and flexible repertoire of (L2) English, as well as a basic understanding (at least among EMI teachers) of basic principles of second language learning and teaching. Furthermore, it demands effective communication skills and strategies-including skills in intercultural communication (Kramsch, 
2011), as well as knowledge of state-of-the-art pedagogical techniques for facilitating learning. Taken together, the range of knowledge bases that might inform the implementation of EMI point to an exceptionally inter- or perhaps transdisciplinary enterprise (Douglas Fir Group, 2016). Closely tied to this interdisciplinarity is the existence of critical perspectives on EMI, the import of which constitute another key 'lesson learned.'

\section{The Critical Dimension}

This final commentary aims to prompt greater reflection in EMI teacher training programs on the larger implications of introducing EMI in higher education institutions. As is likely well-known to the readership of this journal, a critical perspective entails the deconstruction of what is taken for granted as natural, normal, or 'orderly' (Fairclough, 2013). Such a perspective peels away surfacelevel appearances, guises, and/or claims, in order to reveal the underlying political and ideological dimensions, power struggles, and agentive work at play. In other words, a critical perspective seeks to understand more deeply the causes, meanings, and consequences of observed phenomena (e.g.. the introduction of EMI programs, along with, e.g., advertisements, university websites, policy statements, and social media related to those programs), to frame those observations in terms of power dynamics, and, ideally, to attempt to rectify observed wrongs in the quest for social justice and equity (Blommaert, 2005; Fairclough, 2013).

Universities or EMI programs may claim, in the name of internationalization, for example, that offering classes in English broadens students' future prospects for participating in the global economy, gives students a more 'global' perspective on the content they are studying, and promotes multilingualism (see, e.g., Dafouz, 2018). However, one wonders in what ways, specifically, courses incorporate 'global perspectives,' and how such perspectives are built up coherently across the curriculum; in otherwords, one may wonder, 'Are EMI instructors deliberately incorporating perspectives, debates, and/or current challenges from other sociocultural contexts, educational traditions, and subject positions, or are they simply teaching the same (L1) content translated into English?'

Furthermore, given students' and teachers' variable levels of language proficiency and the possible limitations to comprehension this may introduce (Shohamy, 2013), one wonders how much content is actually being learned. Similarly, even though English language learning may not be an explicit goal of EMI programs (i.e., language objectives may not be included in course syllabi), language development is clearly an implied outcome (Pecorari \& Malmström, 2018). Yet, considering the conditions that are generally believed to foster incidental language learning (Hulstijn, 2013), and EMI's characteristic lack of language support of students and teachers alike, one wonders how much incidental language learning is actually taking place in EMI settings. Finally, in regards to multilingualism, it has been suggested that "internationalization policies [which] drive universities to implement English-medium education... generally pose a threat to goals of multilingualism and linguistic diversity" (Goodman, 2014, p. 130). Given the hegemonic status of English as the language of international communication, this is perhaps not surprising. However, if this is in fact the case, then the goals of promoting linguistic diversity may not be fully realized, or may result in different languages receiving disproportionate representation (Shohamy, 2013).

In light of the above, it is perhaps no mystery that within "the economies of education as a globalized good" (Coleman et al., 2018, p. 703), in which internationalization serves a tool for recruiting fee-paying international students and achieving higher rankings, EMI programs play a strategic role that should be critically explored with faculty. As a form of symbolic capital (Coleman et al., 2018; Dafouz, 2018; Kanno \& Norton, 2003), EMI programs-and the English language more generally-bring with them a set of values, status, and prestige that at once affords certain privileges and benefits, while simultaneously devaluing and marginalizing other forms of cultural production. If, for example, teachers find that they must exert more time and energy to teach classes through 
the medium of English (instead of their L1), are stymied from exercising their normal classroom teaching practice, such as using humor (Kling, 2019), and are denied any ostensive university support or financial compensation (as it often the case, cf. Martinez, 2016), EMI teacher education programs must highlight these costs and contrast them with the relative benefits of introducing EMI.

Ultimately, the takeaway 'lesson' is that, in EMI teacher education programs, addressing language skills and teaching methodology is not enough: Teachers must also critically engage with the larger global and historical context within which these activities take place. To do so, EMI teacher education programs need to incorporate a critical, reflexive approach to practice and pose critical questions such as who are we (as professors, as a university) in the bigger picture of education and internationalization? What is at stake by offering classes in English (and, e.g., not in the local language)? To what extent are the purported benefits of internationalization and EMI actually borne out for students, faculty, and the greater society?

\section{Discussion}

At present, EMI teacher education programs are few in number and this presents a challenge for the viability of EMI implementation. As the "final arbiters of language policy implementation" (Garcia \& Menken, 2010, p. 1), EMI instructors must possess the language, teaching, and communication skills needed to carry out effective instruction in English and would further benefit from an understanding of the larger historical and ideological underpinnings of EMI (Coleman et al., 2018). As Farrell (2019) notes, "A gap exists between the top-down pressure to incorporate EMI programs and the bottom-up EMI teacher implementation of these programs [which often occurs] without any real institutional support or clear pedagogical guidelines to follow" (p. 2). The EMI Support Course at USB constituted an initial effort to rectify this situation at one university in the south of Brazil.

Regardless of whether teachers have ready access (i.e., on campus) to professional development programs at their institutions, a grassroots effort will likely be needed to sustain the development of the pedagogical, communicative, and linguistic skills needed for effective teaching through the medium of English. Though many applied linguists have challenged the relevance of a priori notions of language proficiency in multilingual academic contexts such as EMI (Canagarajah, 2013; 2017; Jenkins, 2014; Jenkins \& Leung, 2017), the individual or collective perspectives of different stakeholder groups, as well as various contextual factors (e.g., time, teaching and learning resources) must also be taken into consideration and valued when planning EMI teacher education programs. Without careful consideration of such environmental factors (Nation \& Macalister, 2010), such courses run the risk of losing relevance and, at worst, imposing a set of practices that run counter to local norms, needs, and expectations.

Ensuring that EMI teacher education brings in as many relevant perspectives as possible and is representative of the diverse disciplinary traditions of the faculty participants points to need for an interdisciplinary approach. Interdisciplinarity is a defining characteristic of EMI-whether conceived at the level of policy or practice-and should therefore be central to teacher education curricula. Lastly, the introduction of EMI and the broader goals of internationalization are not neutral activities; they bring with them a set of values, affordances, and consequences that must also be considered by present or potential EMI instructors. Having a critical understanding of what EMI entails will help equip teachers with knowledge and strategies to make informed decisions about their teaching, which may ultimately lead to more equitable and enjoyable teaching and learning experiences for all.

While many scholars (cf. Coleman et al., 2018, pp. 702-703) make a distinction between EMI and the higher education contexts where English is commonly used as a first or additional language by the majority of the population (e.g., Australia, the United States), this view may be gradually shifting (Y. Matsumoto, personal communication, February 9, 2020). For example, in Pecorari and 
Malmström's (2018) review of 513 EMI studies, in which they sought to discover how the term "EMI" is used and the extent to which usage of the term varied in published research, the authors found that approximately $25 \%$ of the studies were carried out in contexts "where English is the first language or one of several dominant and/or official languages" (p. 506). Based on this finding, they concluded that "EMI settings can legitimately be said to include those where English is the L1 for more than a fraction of the population" (p. 506). Following this line of reasoning, it could be suggested that many of the challenges related to EMI described in this paper and elsewhere (e.g., Macaro et al., 2018) have actually become endemic to 'unmarked,' 'inner-circle' contexts as well (Coleman et al., 2018; Kachru, 1997). In this sense, we may start to rethink some assumptions about language, education, and the role of language in education in all contexts (Hult, 2008), which may lead us to reimagine basic notions such as 'successful communication' and 'good teaching' (see also Ball \& Lindsay, 2013, p. 49). As Coleman et al. (2018) observe, "Having a bad teacher is likely to be more detrimental to learning than being taught in what is not your first language" (p. 714).

\section{Conclusion}

This paper set out to highlight some of the key insights gained from piloting an EMI teacher education course at a university in the south of Brazil. Though these insights were backed by observations, findings from course evaluation data, as well as evidence from the literature, clearly more research is needed on EMI teacher training to substantiate these claims. Indeed, Macaro et al. (2018) point out that "there is...virtually no research data available on types of teacher preparation programmes in EMI in HE Ihigher education]" (p. 56). Thus, at present, we really do not know how effective teacher education programs are; we don't know what aspects of pedagogy, communication, or language use change (or improve) as a result of participating in EMI teacher training; and we don't know what activities, tasks, and assessments are most useful for EMI teachers' professional development.

What we do seem to know, based on the limited number of EMI teacher education studies that exist, is that teacher training has the potential to raise both pre- and in-service EMI instructors' awareness of key issues surrounding EMI implementation. We also know that many teachers consider such opportunities an invaluable and indispensable aspect of principled EMI implementation (Ball \& Lindsay, 2013; Goodman, 2014). The real challenge, then, is to increase the number of EMI teacher education programs and to start collecting data on their impact.

\section{Disclosure Statement}

The author declares no financial or other substantive conflict of interest with respect to the interpretation of this manuscript.

\section{References}

Ball, P., \& Lindsay, D. (2013). Language demands and support for English-medium instruction in tertiary education. Learning from a specific context. In A. Doiz, D. Lasagabaster, \& J.M. Sierra (Eds.), English-medium instruction at universities: Global challenges, (pp. 44-66). Bristol: Multilingual Matters. https://doi. org/10.21832/9781847698162-007.

Baumvol, L., \& Sarmento, S. (2019). Can the use of English as a medium of instruction promote a more inclusive and equitable higher education in Brazil?. SFU Educational Review, 12(2), p. 87-105. https://journals.lib. sfu.ca/index.php/sfuer/article/view/941. https://doi. org/10.21810/sfuer.v12i2.941.

Blommaert, J. (2005). Discourse: A critical introduction Cambridge: Cambridge University Press. https://doi. org/10.1017/CBO9780511610295.

Borsetto, E., \& Schug, D. P. (2016). English support to academic staff. Annali di Ca' Foscari. Serie occidentale, 50, p. 9-28. doi: 10.14277/2499-1562/AnnOc-50-16-1.

Burns, A. (2010). Doing action research in English language teaching: A guide for practitioners. New York, NY: Routledge. https://doi.org/10.4324/9780203863466.

Canagarajah, S. (2013). Translingual practice: Global Englishes and cosmopolitan relations. London: Routledge. https://doi.org/10.4324/9780203120293.

Canagarajah, S. (2017). Translingual practice as spatial repertoires: Expanding the paradigm beyond structuralist orientations. Applied Linguistics, 39, p. 31-54. https://doi.org/10.1093/applin/amx041 
Coleman, J., Hultgren, K., Li, W., Tsui, C., \& Shaw, P. (2018). Forum on English-medium instruction. TESOL Quarterly, 52(3), 701-720. doi: 10.1002/tesq.469

Corrigan, P. C. (2015). Designing a pre-service teacher education course in English for the medium of instruction. Asian EFL Journal, 88, p. 97-112. https://scholars. cityu.edu.hk/en/publications/publication(a293f59b-b3do-4913-adb6-8b9923bfbgod).html.

Dafouz, E. (2018). English-medium instruction and teacher education programmes in higher education: Ideological forces and imagined identities at work. International Journal of Bilingual Education and Bilingualism, 21(5), p. 540-552. doi:10.1080/13670050.2018.1487926

Dearden, J. (2015). English as a medium of instruction: A growing global phenomenon. London, England: British Council.

Douglas Fir Group. (2016). A transdisciplinary framework for SLA in a multilingual world. Modern Language Journal, 100, p. 19-47. https://doi.org/10.1111/modl.12301

Drljača Margić, B., \& Vodopija-Krstanović, I. (2018). Language development for English-medium instruction: Teachers' perceptions, reflections and learning. Journal of English for Academic Purposes, 35, p. 31-41. doi:10.1016/j.jeap.2018.06.005

Fairclough, N. (2013). Critical discourse analysis: The critical study of language. New York, NY: Routledge. https://doi.org/10.4324/9781315834368.

Farrell, T. (2019). Professional development through reflective practice for English-medium instruction (EMI) teachers. International Journal of Bilingual Education and Bilingualism, 23(3), p. 277-286. doi:10.1080/13670 050.2019.1612840.

Freeman, D., Katz, A., Garcia, G. P., \& Burns, A. (2015). English-for-teaching: Rethinking teacher proficiency in the classroom. ELT Journal, 69(2), p. 129-139. http:// dx.doi.org/10.1093/elt/ccu074

Gimenez, T., Sarmento, S., Archanjo, R., Zicman, R., \& Finardi, K. (2018). Guide to English as a medium of instruction in Brazilian higher education institutions 2018-2019. São Paulo: British Council.

Goodman, B. (2014). Implementing English as a medium of instruction in a Ukrainian university: Challenges, adjustments, and opportunities. International Journal of Pedagogies and Learning, 9(2), p. 130-141. https:// doi.org/10.1080/18334105.2014.11082026

Hahl, K., Järvinen, H. M., \& Juuti, K. (2016). Accommodating to English-medium instruction in teacher education in Finland. International Journal of Applied Linguistics, 26(3), p. 291-310. https://doi.org/10.1111/ijal.12093

Hulstijn, J. H. (2013). Incidental learning in second language acquisition. In C. A. Chapelle (Ed.), The encyclopedia of applied linguistics v. 5, pp. 2632-2640. Chichester: Wiley-Blackwell. https://doi.org/10.1002/9781405198431. wbeal0530

Hult, F. (2008). The history and development of educational linguistics. In B. Spolsky, \& F. Hult (Eds.), The handbook of educational linguistics, (pp. 10-24). Malden, MA: Blackwell. https://doi.org/10.1002/9780470694138.ch2.
Jenkins, J. (2014). English as a lingua franca in the international university: The politics of academic English language policy. London: Routledge. https://doi. org/10.4324/9780203798157.

Jenkins, J., \& Leung, C. (2017). Assessing English as a lingua franca. In E. Shohamy, I. G. Or, \& S. May (Eds.), Language testing and assessment (3rd ed.) of S. May (Ed.), Encyclopedia of language and education, (pp. 103-117). New York, NY: Springer. https://doi.org/10.1007/9783-319-02261-1_-7.

Kachru, B. (1997). World Englishes and English-using communities. Annual Review of Applied Linguistics, 17 , pp. 66-87. https://doi.org/10.1017/S0267190500003287.

Kanno, Y., \& Norton, B. (2003). Imagined communities and educational possibilities: Introduction. Journal of Language, Identity, and Education, 2(4), pp. 241-249. doi: 10.1207/S15327701JLIE0204_1.

Kim, T. (2009). Transnational academic mobility, internationalization and interculturality in higher education. Intercultural Education, 20(5), pp. 395-405. doi: 10.1080/14675980903371241.

Kling, J. (2019). TIRF language education in review: English as a medium of instruction. Monterey, CA \& Baltimore, MD: TIRF \& Laureate International Universities.

Knight, J. (2003). Updating the definition of internationalization. International Higher Education, 33, p. 2-3. Retrieved from https://ejournals.bc.edu/index.php/ ihe/issue/view/761

Kramsch, C. (2011). The symbolic dimensions of the intercultural. Language Teaching, 44(3), pp. 354-367. https://doi.org/10.1017/S0261444810000431

Macaro, E., Curle, S., Pun, J., An, J., \& Dearden, J. (2018). A systematic review of English medium instruction in higher education. Language Teaching, 51, pp. 36-76. https://doi.org/10.1017/S0261444817000350

Martinez, R. (2016). English as a medium of instruction (EMI) in Brazilian higher education: Challenges and opportunities. In K., Finardi (Ed.), English in Brazil: views, policies and programs (pp. 191-228). Londrina: Eduel.

Menken, K., \& Garcia, O. (2010). Introduction. In K. Menken, \& O. Garcia (Eds.), Negotiating language policies in schools: Educators as policymakers (pp. 1-10). New York, NY: Routledge. https://doi.org/10.4324/9780203855874.

Nation, I.S.P., \& Macalister, J. (2010). Language curriculum design. New York, NY: Routledge.

O'Dowd, R. (2018). The training and accreditation of teachers for English medium instruction: An overview of practice in European universities. International Journal of Bilingual Education and Bilingualism, 21(5), pp. 553-563. doi:10.1080/13670050.2018.1491945

Pecorari, D., \& Malmström, H. (2018). At the crossroads of TESOL and English medium instruction. TESOL Quarterly, 52(3), pp. 497-514. doi: 10.1002/tesq.470. 
Pusey, K., Del Corona, M., \& Schnack, C. M. (2021, March 24-27). Supporting English medium instruction at a southern Brazilian university. Paper to be presented at the TESOL International Convention \& English Language Expo [online].

Richards, J.C., \& Lockhart, C. (1996). Reflective teaching in second language classrooms. New York, NY: Cambridge University Press.

Shohamy, E. (2013). A critical perspective on the use of English as a medium of instruction at universities. In A. Doiz, D. Lasagabaster, \& J.M. Sierra (Eds.), English-medium instruction at universities: Global challenges (pp. 196-210). Bristol: Multilingual Matters. https://doi. org/10.21832/9781847698162-014.

Times Higher Education (n.d.). Study in Brazil. Retrieved March 29, 2020, from https://www.timeshighereducation.com/student/where-to-study/study-in-brazil\#survey-answer.

Toh, G. (2016). English as medium of instruction in Japanese higher education: Presumption, mirage or bluff?. London, UK: Palgrave Macmillan. https://doi. org/10.1007/978-3-319-39705-4.

Wenger-Trayner, E, \& Wenger-Trayner, B. (2015). Communities of practice. A brief introduction. http://wenger-trayner.com/wp-content/uploads/2015/04/07-Brief-introduction-to-communities-of-practice.pdf.

Wilkinson, R. (2013). English-medium instruction at a Dutch university: Challenges and pitfalls. In A. Doiz, D. Lasagabaster, \& J.M. Sierra (Eds.), English-medium instruction at universities: Global challenges (pp. 3-24). Bristol: Multilingual Matters. https://doi. org/10.21832/9781847698162-005.

\section{Mailing address:}

Kerry Pusey

University of Pennsylvania

3700 Walnut Street, 19104

Philadelphia, PA, Estados Unidos. 